\begin{tabular}{|c|c|}
\hline 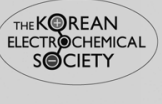 & $\begin{array}{c}\text { Journal of Electrochemical Science and Technology } \\
\text { jecst.kecs.or.kr }\end{array}$ \\
\hline
\end{tabular}

\title{
Materials and Electrochemistry: Present and Future Battery
}

\author{
Subir Paul* \\ Department of Metallurgical and Material Engineering Jadavpur University, Kolkata, India
}

\begin{abstract}
Though battery chemistry and technology had been developed for over a hundred years back, increase in demand for storage energy, in the computer accessories, cell phones, automobile industries for future battery car and uninterrupted power supply, has made, the development of existing and new battery, as an emerging areas of research. With innovation of high energetic inexpensive Nano structure materials, a more energy efficient battery with lower cost can be competitive with the present primary and rechargeable batteries. Materials electrochemistry of electrode materials, their synthesis and testing have been explained in the present paper to find new high efficient battery materials. The paper discusses fundamental of electrochemistry in finding true cell potential, overvoltages, current, specific energy of various combinations of anode-cathode system. It also describes of finding the performance of new electrode materials by various experiments viz. i. Cyclic Voltammetry ii. Chronoamperometry iii. Potentiodynamic Polarization iv. Electrochemical Impedance Spectroscopy (EIS). Research works of different battery materials scientists are discussed for the development of existing battery materials and new nano materials for high energetic electrodes. Problems and prospects of a few promising future batteries are explained.
\end{abstract}

Keywords : Future Batteries, Exiting Battery Materials, Nano Electrodes Materials, Electrochemical Characterization

Received : 28 April 2016, Revised : 23 May 2016, Accepted : 25 May 2016

\section{Introduction}

Increase in demand for pollution free energy has necessitated the development of existing battery and finding new materials system for future battery so that the electrochemical energy can be synthesized at economically cheaper rate.

The energy produced and stored in a battery is a pure electrochemical and dependent on electrochemical science and engineering on the electrodes, electrolytes and the reversible reactions. Thus to develop the existing battery and to form new battery with inexpensive materials, one has to first understand the basis principle and theory of battery electrochemistry.

A battery is a form of storing electrical energy, produced by chemical energy conversion through the electrochemical reactions at the anode and cathode. Combination of any two half cell reactions, one act-

*E-mail address: spaul@metal.jdvu.ac.in

DOI: http://dx.doi.org/10.5229/JECST.2016.7.2.115 ing as anodic and other as cathodic may be the $1^{\text {st }}$ initial step of forming a battery. The cell potential can be obtained from the equation

$$
\mathrm{E}_{\text {Cell }}^{\mathrm{o}}=\mathrm{E}_{\text {Red,Cathode }}^{\mathrm{o}}-\mathrm{E}_{\text {Red,Anode }}^{\mathrm{o}}
$$

If the half cell potential of the anodic and cathodic reactions is not available in the literature, then the cell potential of the battery can be computed from the following equation.

$$
\Delta \mathrm{G}=-\mathrm{nFE}
$$

Where $\Delta \mathrm{G}$ is the free energy for the overall reaction, that can be found ou from the thermodynamic data handbook, $\mathrm{n}$ is the number of electron involved in each half cell reaction and $\mathrm{F}$ is the faraday 96500 coulombs.

There are a large number of elements and compounds from which to select the potentially useful combinations for batteries. For example for $\mathrm{Pb}$ - acid battery, cell potential is obtained as follows. 


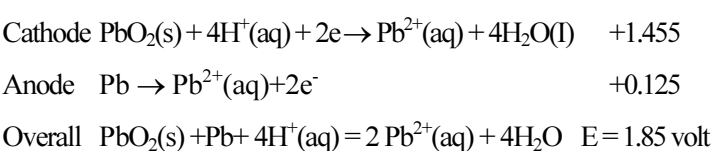

The standard cell potential obtained is $1.85 \mathrm{~V}$

If the half cell electrode potential is difficult to experimentally determine, for example, for a reactive metal $\mathrm{Mg}$ and gas $\mathrm{Cl}_{2}$, one can find the free energy of formation of $\mathrm{MgCl}_{2}$ as $-591.8 \mathrm{kj} / \mathrm{m}$ (Thermodynamic data handbook). Using this value cell potential is computed using Eqn. 2 as

$$
\mathrm{E}=(591.8 \times 1000) /(2 \times 96500)=3.06 \mathrm{~V}
$$

It is to be noted that a battery made of reactive elements and compound produces a very high cell potential.

Similarly such high potential battery can be made with $\mathrm{Si}$ or other reactive metals but one needs to develop the electrochemical science and technology for a such battery. The design of the cell needs to be such that the reaction is electrochemical, not chemical; that is anodic and cathodic reactions are separated by a separator such as a membrane so that the electron released from the oxidation at anode is transported through the external load to the cathode which takes up this electron to complete the reduction reaction at cathode.

The current produced by the battery depends on many factors as follows:

1) The anode and cathode need to be made of high energetic electro catalytic materials. That is anode has the capacity to release electron at a fast rate and the cathode to accept the same at the highest rate. This will give rise to a high current from cell and more energy with a given cell potential.

2) The anode or cathode should not corrode or chemically react with the electrolyte substances except the electrode reactions itself (if any).

3) The anode or cathode should have a higher surface area to volume ratio to have more areas of reaction sites and hence more current. If the electrodes synthesized as Nano structured materials will have enhanced surface area, besides the high electronic conductivity.

4) The electrolytes should be chemically stable during the operation of the cell and have high ionic conductivity to make IR energy loss minimum.
5) For rechargeable battery, the reactions (discharge/charge) must be reversible. The energy storage and release cycles need to be high with a steady and good cell potential and current.

6) Inexpensive anode and cathode materials should be developed to produce energy at a lower cost

7) The materials of the battery, including the casing should not be a environment hazard problems.

Research and developments are going on existing and future batteries with new materials. Materials and electrochemical characterization are carried out on battery materials to come out with a high performance - low cost battery to take the battery industry to the next level.

\section{Electrochemical Characterization of Cell}

The performance of a battery is decided by its actual cell potential, the current delivering capacity and specific energy. The practical onload cell potential is much less than the theoretical cell potentials due to various overvoltages at anode and cathode plus the electrolyte resistance. The current produced by the battery is much dependent on the electrochemical properties of the electrodes materials plus electrochemical battery reaction.

\subsection{Cell Potential, $\mathbf{E}_{\text {cell }}$}

The anodic reaction at anode-electrolyte interface is an electrochemical oxidation with a half cell potential under standard state is $\mathrm{E}_{\mathrm{a}}^{0}$. The cathodic reaction at cathode-electrolyte interface is a reduction reaction with a standard half cell potential $\mathrm{E}_{\mathrm{c}}^{0}$.

The open circuit standard cell potential of the battery is

$$
\mathrm{E}_{\text {cell }}^{0}=\mathrm{E}_{\mathrm{c}}^{0}-\mathrm{E}_{\mathrm{a}}^{0}
$$

But if the reactants and products are not at the standard conditions, the cell potential is found by the Nernst equation as follows.

For an overall reaction, consisting of two half cell reactions of anode and cathode

$$
\begin{aligned}
& \mathrm{aA}+\mathrm{bB}=\mathrm{cC}+\mathrm{dD} \\
& \mathrm{E}_{\text {cell }}=\mathrm{E}_{\text {cell }}^{0}-(\mathrm{RT} / \mathrm{nF}) \ln \left(\left[\left(\mathrm{a}_{\mathrm{C}}\right)^{\mathrm{c}}\left(\mathrm{a}_{\mathrm{D}}\right)^{\mathrm{d}}\right] /\left[\left(\mathrm{a}_{\mathrm{A}}\right)^{\mathrm{a}}\left(\mathrm{a}_{\mathrm{B}}\right)^{\mathrm{b}}\right]\right)
\end{aligned}
$$

Let us take an example of $\mathrm{Zn} / \mathrm{Cl}_{2}$ battery

At Anode $\mathrm{Zn}=\mathrm{Zn}^{+2}+2 \mathrm{e} \mathrm{E}_{\mathrm{a}}^{0}=0.76 \mathrm{v}$ 
At cathode $\mathrm{Cl}_{2}+2 \mathrm{e}=2 \mathrm{Cl}^{-} \mathrm{E}^{0}{ }_{\mathrm{c}}=1.36 \mathrm{v}$

Overall $\mathrm{Zn}+\mathrm{Cl}_{2}=\mathrm{ZnCl}_{2} \mathrm{E}_{\text {cell }}^{0}=2.12 \mathrm{v}$

$\mathrm{E}_{\text {cell }}=\mathrm{E}_{\text {cell }}^{0}-(\mathrm{RT} / 2 \mathrm{~F}) \ln \left(\left[\left(\mathrm{ZnCl}_{2}\right) /\left(\mathrm{Zn}^{+2}\right)\left(\mathrm{Cl}_{2}\right)\right]\right)$

If the pressure of $\mathrm{Cl}_{2}$ is 1 atm and $\mathrm{ZnCl}_{2}$ is pure substance, $\mathrm{Zn}^{+2}$ at 1 molar concentration

$$
\begin{aligned}
& \text { At } \mathrm{T}=298 \mathrm{~K} \quad \mathrm{RT} / \mathrm{F}=0.059 \mathrm{~V} \\
& \mathrm{E}_{\text {cell }}=2.12-0.0285 \ln (1 / 0.1)=2.044 \mathrm{~V}
\end{aligned}
$$

The Eqn. 4 gives open circuit potential of the cell.

One can find the cell potential of other combinations of anode and cathode, using the table of standard electrode potential.

\subsection{Overvoltage and On-load Cell Potential}

The cell potential obtained by Eqn. 4 decreases, the moment the +ve and -ve terminals are connected to an external load. This is due to the polarizations of the electrode, the magnitude represented by overvoltage $h$ and internal resistance of the cell. The net cell potential is given by the Eqn. 5 .

$$
\mathrm{E}_{\text {cell, net }}=\mathrm{E}_{\text {cell }}-\eta-\mathrm{IR}
$$

Where $\eta$ is total over voltage at anode and cathode, $\mathrm{R}$ is the electrolyte resistivity, I the current generated by the cell, passing through the external load.

The overvoltage $\mathrm{h}$ has two parts, activation Polarization $\eta_{\text {act }}$ and Concentration Polarization $\eta_{\text {con }}$

So that

$$
\eta=\eta_{\text {act }}+\eta_{\text {con }}
$$

2.2.1. Overvoltage due to activation Polarization $\eta_{\text {act }}$ It is given by Tafel's equation as follows

$$
\eta_{\text {act }}= \pm \beta \log \left(\mathrm{i} / \mathrm{i}_{0}\right)
$$

Where $\beta$ is the Tafel's slope, $i_{0}$ is the exchange current density (See Fig. 1)

$$
\begin{aligned}
& \text { For anodic reaction } \eta_{\text {act, } a}=+\beta_{\mathrm{a}} \log \left(\mathrm{i}_{\mathrm{a}} / \mathrm{i}_{0}\right) \\
& \text { For cathodic reaction } \eta_{\mathrm{act}, \mathrm{c}}=-\beta_{\mathrm{c}} \log \left(\mathrm{i}_{\mathrm{c}} / \mathrm{i}_{0}\right)
\end{aligned}
$$

It is illustrated in Fig. 1, how the net cell potential decreases due to activation overvoltage.
2.2.2. Overvoltage due to Concentration Polarization $\eta_{\text {con }}$ The speed at which the electron is transported at the electrode is much greater than the speed of diffusion of the reacting ions towards the electrode surface. So an electrode reaction is delayed due to non availability of the reacting ions. Due to this fact that is deficiency of the concentration of these ions, the concentration polarization arises. The cell potential decreases due to this concentration overvoltage (Fig. 2). Under the extreme high reaction rate, if the concentration of the ion at the electrode surface becomes zero, it is the limiting case and polarization approaches negative infinity (Fig. 2). The current corresponding to this situation is the limiting current density $i_{L}$. The concentration

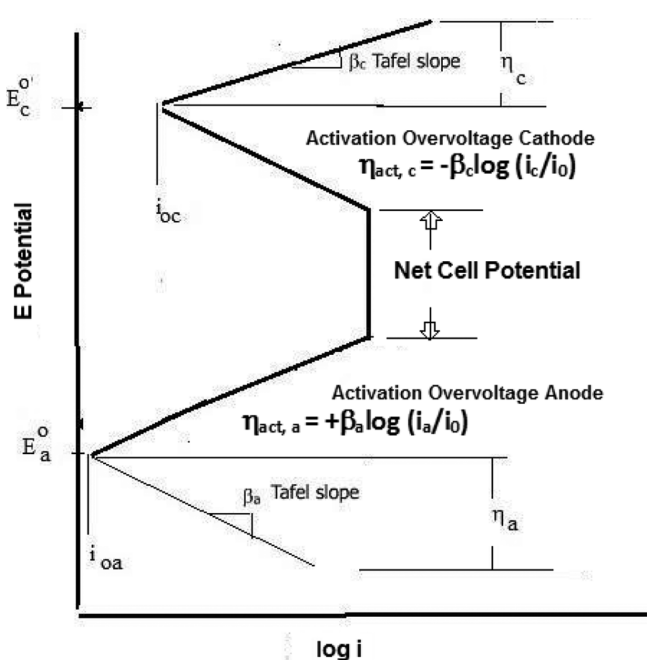

Fig. 1. Effect of activation Polarization on cell potential.

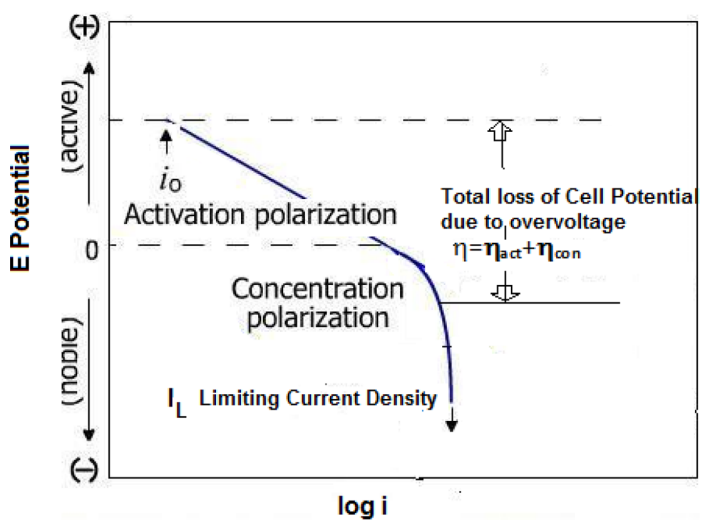

Fig. 2. Activation and Concentration Polarization combined, It shows loss of cell potential from what is available from half cell potential due to activation and concentration overvoltage. 
overvoltage is given by the following equations

$$
\begin{aligned}
& \eta_{\text {con }}=2.33 R T /(n F) \log \left(1-\mathrm{i}_{1} \mathrm{i}_{\mathrm{L}}\right) \\
& \mathrm{i}_{\mathrm{L}}=\mathrm{DnFC}_{\mathrm{B}} / \mathrm{d} \\
& \eta_{\text {con,a }}=2.33 \mathrm{RT} /(\mathrm{nF}) \log \left(1-\mathrm{i}_{\mathrm{a}} / \mathrm{i}_{\mathrm{L}}\right)
\end{aligned}
$$

(Overvoltage at anode)

$$
\eta_{\text {con, }}=2.33 R T /(n F) \log \left(1-i_{c} / i_{L}\right)
$$

(Overvoltage at cathode)

So the net cell potential is given by the Eqn. 9

$$
\mathrm{E}_{\mathrm{cell}, \text { net }}=\mathrm{E}_{\mathrm{cell}}-\eta_{\text {act,a}}-\eta_{\text {act,c }}-\eta_{\text {con,a }}-\eta_{\text {con,a }}-\mathrm{IR}
$$

The net cell potential with all losses due to overvoltage is shown in Fig. 3.

So to get a high cell potential and hence energy, all the overvoltage terms in the equation above need to be reduced by developing high electrocatalytic electrode materials (anode \& cathode) and low electrolyte resistance $R$.

The current $\mathrm{I}=\mathrm{E}_{\text {cell, } \text { net }} / \mathrm{R}_{\mathrm{L}}$

Where $\mathrm{R}_{\mathrm{L}}$ is the external load

\subsection{Energy}

The energy generated by a battery is measured by the number of amperes produced $\times$ the unit of time $\times$ the average voltage over that time. Taking the example of $\mathrm{Zn} /$ $\mathrm{Cl}_{2}$ battery as stated above, with atomic wt of $\mathrm{Zn}$ 65.4. 1 mole of substance produces 96487 coulombs of charge

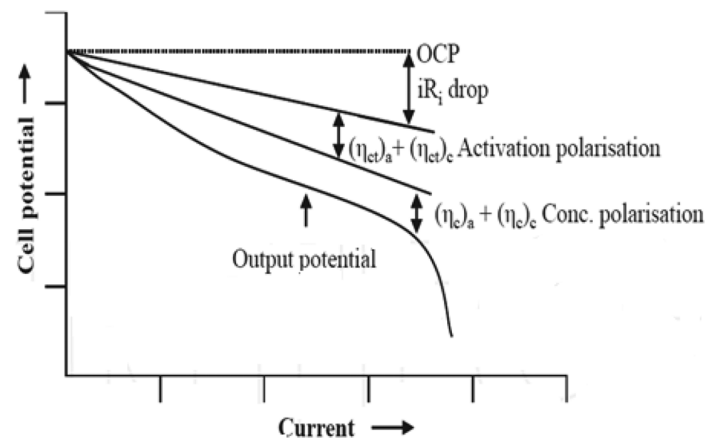

Fig. 3. Net Cell Potential. It shows how the real cell potential is decreased from theoretical cell potential by polarization and IR drop.

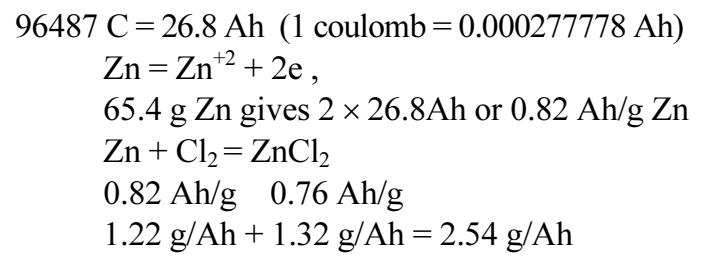

That is $0.394 \mathrm{Ah} / \mathrm{g}$ of cell anode and cathode material consumption.

If the cell operates at $1.5 \mathrm{~V}$ (Open circuit potential $2.0 \mathrm{~V}$, see Eqn. 4, minus all overvoltages (see Eqn. 9)

Then the specific energy $=0.394 \times 1.5=0.591$ watt-hour/g. or 38 watts-hour DC energy per mole $\mathrm{Zn}$

$$
\begin{aligned}
\mathrm{G} & =\text { Energy }=\mathrm{IE}_{\text {cell,net }} \cdot \mathrm{h} \\
& =\text { ampere. } \text { voltage. } h \text { hour }=\text { watt-hour }
\end{aligned}
$$

Electrode material consumption and Specific Energy

So specific energy $\mathrm{G}_{\mathrm{sp}}=\left(\mathrm{E}_{\text {cell,net. }}\right.$. $\left.\mathrm{h}\right) / \mathrm{M}$

Where $\mathrm{M}$ is the aggregate mass of anode consumption and product generation at cathode

The performance of a battery is known from energy vs power curve which is illustrated in Fig. 4. It is seen in the figure that Li ion battery outperforms other batteries. Comparing the curves for new developed battery with those of exiting high performance battery, gives an idea of state of development.

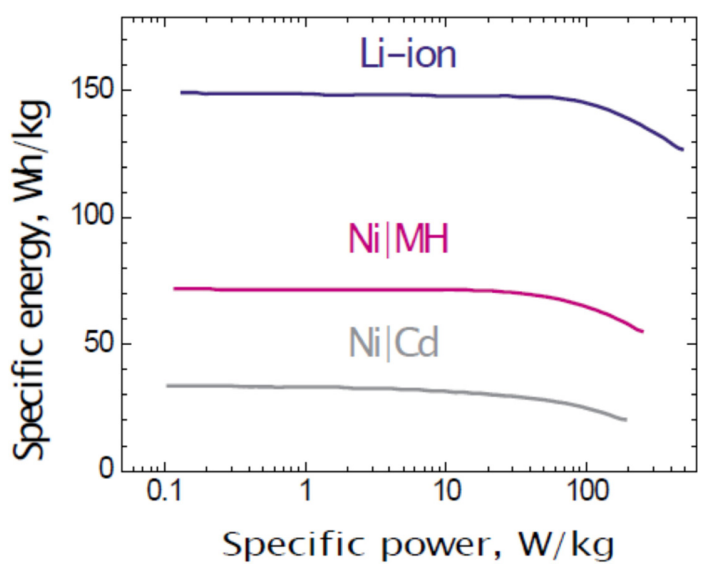

Fig. 4. Energy Power Density. It shows the relation between specific energy with specific power of different battery. 


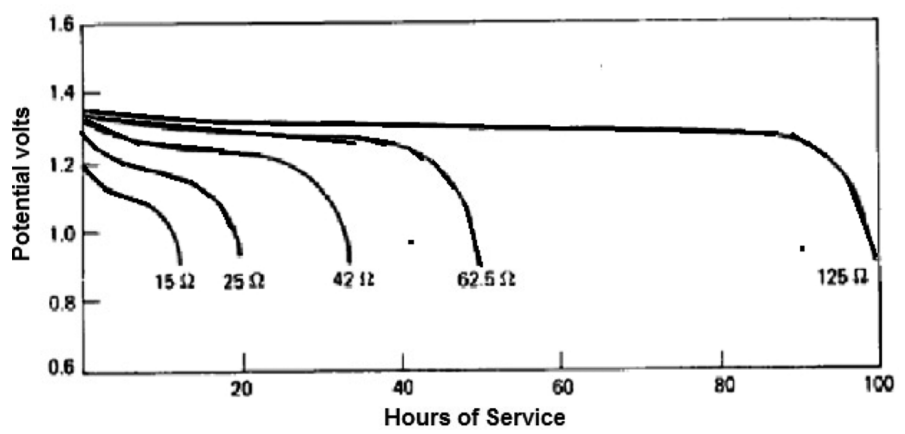

Fig. 5. Battery Drainage. It illustrates typical drainage profile of a cell at different values of external load.

\subsection{Discharge Performance}

For rechargeable battery, discharge performance is performed by studying on-load potential at fixed load with hours of service life. A typical discharge curve is shown in Fig. 5 at different external resistances. It is seen that the higher the external load, the lower is the current and more is the service life of the battery. Thus the test guides the manufacturer about range of load in the application gadgets, for a fixed potential of the battery.

\section{Electrodes Materials Characterization}

The performance of battery materials, specially the electrodes can only be known by various electrochemical laboratory tests. So while developing the future battery, once the anode and cathode materials have been found and synthesized (as described in the next section), the electrochemical energy properties of the materials and their comparison with the existing ones are done by performing the following tests.

1) Cyclic Voltammetry 2) Chronoamperometry 3) Potentiodynamic Polarization 4) Electrochemical Impedance Spectroscopy (EIS)

The cyclic voltammetry and chronoamperometry tests are done to achieve a high and stable current at redox potential so that the battery yields a high specific energy $\mathrm{G}_{\mathrm{sp}}$, as given by Eqn. 12 above. The potentiodynamic polarization and Electrochemical Impedance Spectroscopy tests are performed to aim at developing electrodes of low anode and Cathode overvoltage for anodic and cathodic reactions respectively. Additionally the electrodes must have high hydrogen overvoltage at cathode and high oxygen overvoltage at anode so that $\mathrm{H}_{2}$ and $\mathrm{O}_{2}$ are not evolved from the aqueous electrolyte. The IR drop should be low that is high electrolyte conductivity. So

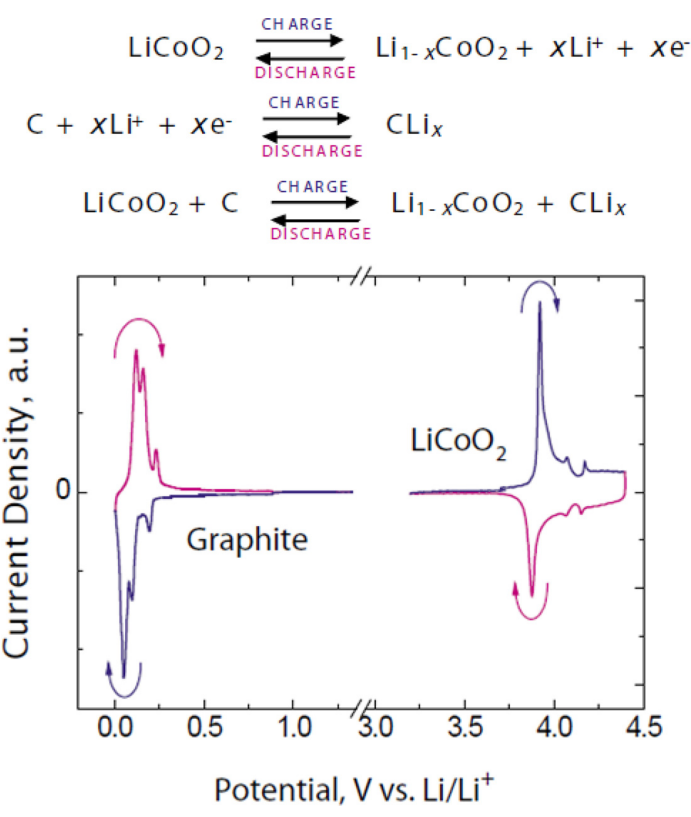

Fig. 6. Cyclic voltammetry (CV). It schematically shows the $\mathrm{CV}$ for anodic and cathodic reaction of $\mathrm{Li}$ ion battery. The blue and magenta colors represent charge and discharge respectively.

the net cell potential $\mathrm{E}_{\text {cell, net, }}$ given by Eqn. 9 is high. Finally the E-I characteristics of the fabricated battery is studied by varying different external load.

\subsection{Cyclic Voltammetry (CV)}

In $\mathrm{CV}$ potential is scanned, staring from a potential well below the potential for cathodic reduction of the half cell reaction to the potential of anodic oxidation of other half cell reaction. In cyclic Voltammetry curve, two peaks can be observed: cathodic reduction and anodic oxidation of the ions [3,4]. Fig. 6 shows a cyclic Voltammetry curve for cathode (graphite) and anode $\left(\mathrm{LiCoO}_{2}\right)$ materials for Li-ion battery. The 


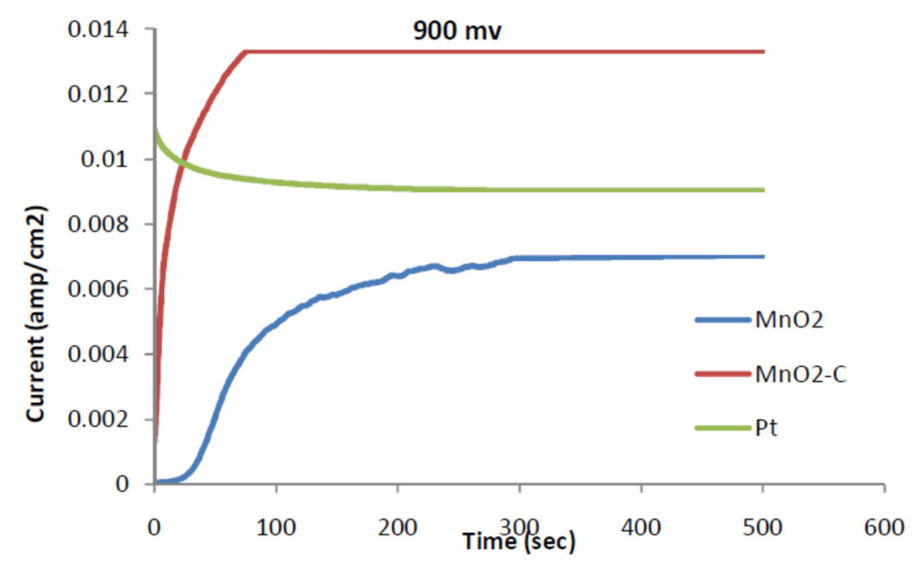

Fig. 7. Chronoamperometry ( $\mathrm{I}$ vs t) curve of electrodes $\mathrm{MnO}_{2}$ and $\mathrm{MnO}_{2}-\mathrm{Nano}-\mathrm{Carbon}$ compared with that of Pt at $900 \mathrm{mV}$ vs SCE fixed potential in glucose solution electrolyte.

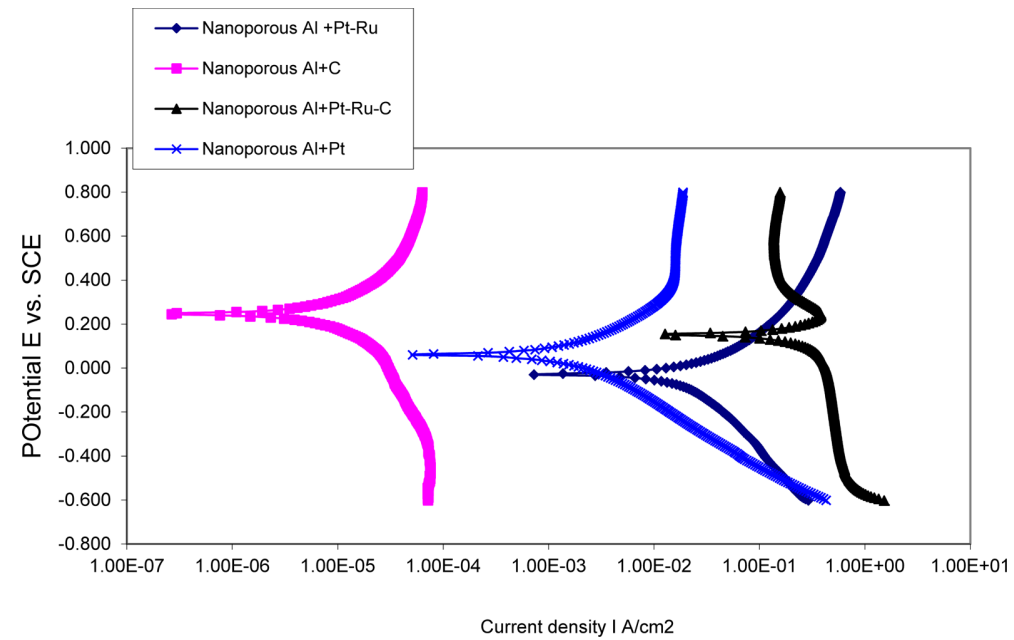

Fig. 8. Polarization characterics of nanoporous anodized Al coated with different materials in anodic solution.

curve shows a peak current density at a fixed potential, indicating the oxidation or anodic reaction at that potential. The higher is the current and the better is the battery materials. The area within the enclosed curve is significant. It indicates the energy content of the battery. So a bigger area is what is wanted for future batteries.

\subsection{Chronoamperometric}

It is conducted to study $I=f(t)$ at different fixed potentials preselected around the cell potential. Such measurement gives us additional qualitative and quantitative information about electrolyte composition, speed of electrode processes and chemical reaction taking place at the electrodes and in electrolyte.
Chronoamperometric curves should be registered at potential exceeding the overpotential value [1-4]. Fig. 7 depicts chronoamperometric curves for $\mathrm{MnO}_{2}$ and $\mathrm{MnO}_{2}$ - Nano Carbon electrode materials. It is worthwhile to mention here that $\mathrm{MnO}_{2}$ is a commercially used battery electrode material and the author had developed $\mathrm{MnO}_{2}$ - Nano Carbon electrode, whose performance in the test is found to be much better than simple $\mathrm{MnO}_{2}$. For comparison, the commonly known high electrocatalytic material, Pt electrode is also taken and $\mathrm{MnO}_{2}$ - Nano Carbon electrode outperforms it by giving the highest steady state current

\subsection{Potentiodynamic Polarization}

This test reveals all electro kinetic parameters such 
Table 1. Electrochemical kinetic parameters for anodic and cathodicreactions.

\begin{tabular}{cccc}
\hline \hline & & Anodic Solution \\
\hline Electrode & Exchange c.d & Reaction rate & Polarization Resistance \\
& $\mathrm{I}_{\mathrm{o}} \mathrm{A} / \mathrm{cm}^{2}$ & $\mathrm{R}_{\mathrm{p}}$ ohmcm $^{2}$ & \\
Anodized Al & $1.84 \times 10^{-8}$ & $2 \times 10^{-5}$ & 140000 \\
$+\mathrm{Pt}$ & $9.52 \times 10^{-7}$ & $2.85 \times 10^{-3}$ & 27000 \\
$+\mathrm{Pt}+\mathrm{Ru}$ & $1.29 \times 10^{-5}$ & $2.12 \times 10^{-2}$ & 2000 \\
$+\mathrm{Pt}+\mathrm{Ru}+\mathrm{C}$ & $1.43 \times 10^{-4}$ & $2.31 \times 10^{-1}$ & 1800 \\
\hline Electrode & & $\mathrm{Cathodic}^{-3}$ solution & \\
\hline & Exchange c.d & Reaction rate & Polarization Resistance \\
Anodized Al & $\mathrm{I}_{\mathrm{o}} \mathrm{A} / \mathrm{cm}^{2}$ & $\mathrm{I}_{\text {corr }} \mathrm{A} / \mathrm{cm}^{2}$ & $\mathrm{R}_{\mathrm{p}}$ ohmcm \\
$+\mathrm{Pt}$ & $2.83 \times 10^{-9}$ & $4.92 \times 10^{-6}$ & $9.08 \times 10^{6}$ \\
$+\mathrm{Pt}+\mathrm{Ru}$ & $5.57 \times 10^{-7}$ & $1.47 \times 10^{-4}$ & 46140 \\
$+\mathrm{Pt}+\mathrm{Ru}+\mathrm{C}$ & $9.94 \times 10^{-7}$ & $5.52 \times 10^{-4}$ & 25855 \\
\hline
\end{tabular}

as Tafel slope, exchange current density, limiting current density, overvoltage [1-5]. Here the potential is scanned from cathodic to anodic side and corresponding current are recorded. Fig. 8 shows typical polarization curves of a few electrodes materials developed by author and his group. One such electrode is nanoporous anodized $\mathrm{Al}$, the pores filled by different combination of precious metals by electrodeposition. In this test, if the curve shifts to the right, the polarization and overvoltage on the electrode material is less and so it is a better electrode material than the one which is left of it. In this figure it is seen that nanoporous anodized aluminum filled up with $\mathrm{Pt}+\mathrm{Ru}+\mathrm{C}$ comes out as the best high energetic electrode material. This electrode comes out as new high energetic electrode material and can be used for future battery development in watch or small electronic gadget. Electrochemical kinetic data derived from the curve in Fig. 8 is shown in the Table 1. It is interesting to find that the electrode material $\mathrm{Pt}+\mathrm{Ru}+\mathrm{C}$ gives lowest polarization resistance $R_{p}$, the highest exchange current density $i_{0}$ and the fast reaction rate.

\subsection{EIS (Electrochemical Impedance Spectroscopy)}

EIS study is carried out for better understanding of the fundamental aspect of the electrochemical phenomenon at the metal-electrolyte interface. The phenomenon at the interface of the solid metal coated surface and aqueous electrolyte is a complex process consisting of line of positive and negatively charged

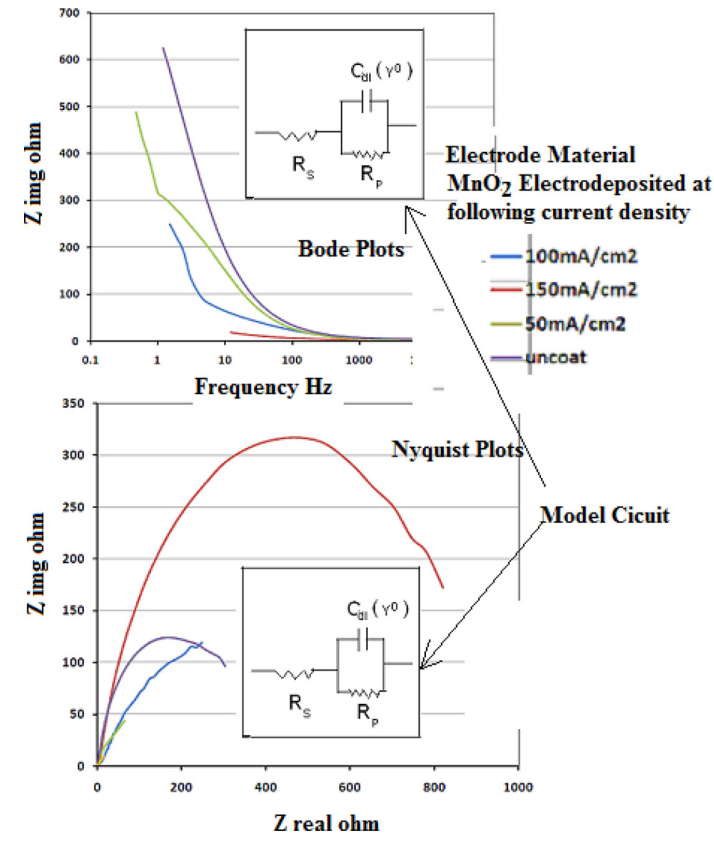

Fig. 9. Electrochemical Impedance Spectroscopy. It illustrates Bode and Nyquist plots of impedance data of the Electrode material $\mathrm{MnO}_{2}$ Electro synthesized at different current density.

ions, capacitance due to double layer, coating or film formation on surfaces, the polarization resistance $\left(R_{p}\right)$, Pore resistance $\left(R_{p o}\right)$ and various impedances due to the diffusion of ions, movement of charge in or away from metal surface and the adsorption of cation and anion. EIS data are plotted in Nyquist and Bode 
Table 2. Computed Electrochemical Impedance Spectroscopy Parameters.

\begin{tabular}{ccccc}
\hline \hline $\begin{array}{c}\mathrm{MnO}_{2} \\
\text { coated at cd }\end{array}$ & $\mathrm{Rp}(\mathrm{Ohms}) \mathrm{Rs}(\mathrm{Ohms})$ & $\begin{array}{c}\mathrm{Y}^{\mathrm{o}}\left(\mathrm{S}^{*} \mathrm{~s}^{\wedge} \mathrm{a}\right) \\
\mu \mathrm{F}\end{array}$ & $\alpha$ \\
\hline $50 \mathrm{~mA} / \mathrm{cm}^{2}$ & 299.1 & 4.802 & 61.87 & 0.272 \\
$100 \mathrm{~mA} / \mathrm{cm}^{2}$ & 81.21 & 4.183 & 66.89 & 0.249 \\
$150 \mathrm{~mA} / \mathrm{cm}^{2}$ & 31.36 & 2.462 & 82.46 & 0.179 \\
\hline
\end{tabular}

plots which show impedance at different frequency for models electrical circuits developed at the metalelectrolyte interface. From the data the following EIS parameters are computed.

Electrolyte resistance $(\mathrm{Ru})$, Double layer capacitance $\left(\mathrm{C}_{\mathrm{dl}}\right)$, Capacitive load or Constant Phase Element, CPE (Y), and $\alpha$ (defined from the capacitive impedance equation $\left.Z=1 / \mathrm{C}(\mathrm{jw})^{-\alpha}\right)$.

EIS is illustrated by $\mathrm{MnO}_{2}$ electrode developed by the author. The bode and Nyquist plots of EIS data for $\mathrm{MnO}_{2}$ electrode material produced by electrodeposition at different current density are shown in Fig. 9 for the matching electrical circuit model, inscribed in the figure. The curves in the Nyquist plots are semicircle type; the less is the diameter of the circle, the better is the electrocatalytic energy material. In case of Bode plots, the lower is the impedance (value of $y$ axis), the electrode material is more energetic. It is seen in both the plots $\mathrm{MnO}_{2}$ electro synthesized at the highest current density comes out as the best electrode material. The EIS parameters computed from the data are illustrated in Table 2. It is seen that polarization resistance $\mathrm{R}_{\mathrm{p}}$ is the minimum and capacitive load is the maximum for $\mathrm{MnO}_{2}$ electro synthesized at the highest current density. So the current flow or rate of electron release from this material will be at the highest rate.

\section{Exiting Battery Materials and Development}

Table 3 illustrates the materials and electrochemistry data of the existing batteries. The battery materials are mainly $\mathrm{Zn}, \mathrm{C}, \mathrm{MnO}_{2}, \mathrm{~Pb}, \mathrm{PbO}_{2}, \mathrm{Ni}, \mathrm{Cd}$ and $\mathrm{Li}$ ion batteries. There is a good scope to further develop these materials. Composite oxides and alloys are good choice to replace the existing electrodes materials. Research works to develop these electrodes materials can improve the performance of the batteries. The oxide materials in the Table 3 can be

Table 3. Exiting Batteries; Materials and Electrochemistry.

\begin{tabular}{|c|c|c|c|c|c|c|c|}
\hline Battery & Anode & Cathode & Electrolyte & Reactions & $\begin{array}{c}\text { Cell } \\
\text { Potential } \\
\text { Volt }\end{array}$ & $\begin{array}{l}\text { Energy } \\
\text { Density } \\
\text { Wh/kg }\end{array}$ & $\begin{array}{l}\text { Life cycle } \\
80 \% \\
\text { discharge }\end{array}$ \\
\hline $\begin{array}{c}\text { Zinc } \\
\text { Carbon }\end{array}$ & $\begin{array}{l}\mathrm{Zn}(\mathrm{Pb}, \mathrm{Cd} \\
\text { inhibitor })\end{array}$ & $\mathrm{MnO}_{2}+\mathrm{c}$ & $\begin{array}{c}\mathrm{NH}_{4} \mathrm{Cl}+\mathrm{ZnCl}_{2} \\
80: 20\end{array}$ & $\begin{aligned} & \mathrm{Zn}+2 \mathrm{MnO}_{2} \\
= & \mathrm{ZnO}+\mathrm{Mn}_{2} \mathrm{O}_{3}\end{aligned}$ & $1.5-1.6$ & $35-50$ & \\
\hline $\begin{array}{l}\text { Alkaline } \\
\mathrm{MnO}_{2}\end{array}$ & Zn powder & $\mathrm{MnO}_{2}(\mathrm{EMD})+\mathrm{C}$ & $35-52 \% \mathrm{KOH}$ & $\begin{array}{c}\mathrm{Zn}+2 \mathrm{MnO}_{2} \\
=\mathrm{Zn}(\mathrm{OH})_{2}+2 \mathrm{MnOOH}\end{array}$ & $1.5-1.6$ & $110-165$ & \\
\hline $\mathrm{Zn}-\mathrm{Ag}_{2} \mathrm{O}$ & $\mathrm{Zn}$ & Silver Oxide & $35-52 \% \mathrm{KOH}$ & $\begin{array}{l}\mathrm{Zn}+\mathrm{Ag}_{2} \mathrm{O}+\mathrm{H}_{2} \mathrm{O} \\
=2 \mathrm{Ag}+\mathrm{Zn}(\mathrm{OH}) 2\end{array}$ & 1.59 & 130 & \\
\hline Zinc-Air & $\mathrm{Zn}$ & $\begin{array}{l}\text { Electro catalytic } \\
\text { MO or Noble M }\end{array}$ & $35-52 \% \mathrm{KOH}$ & $\begin{array}{l}\mathrm{Zn}+1 / 2 \mathrm{O}_{2} \\
=2 \mathrm{Ag}+\mathrm{ZnO}\end{array}$ & 1.65 & 400 & \\
\hline Lead acid & $\mathrm{Pb}$ & $\mathrm{PbO}_{2}$ & Dil $\mathrm{H}_{2} \mathrm{SO}_{4} 3: 1$ & $\begin{array}{c}\mathrm{Pb}(\mathrm{s})+\mathrm{PbO} 2(\mathrm{~s}) \\
+2 \mathrm{H} 2 \mathrm{SO} 4(\mathrm{aq}) \leftrightarrow \\
2 \mathrm{PbSO} 4(\mathrm{~s})+2 \mathrm{H} 2 \mathrm{O}(\mathrm{l})\end{array}$ & 2.0 & $30-50$ & $200-300$ \\
\hline $\mathrm{Ni}-\mathrm{Cd}$ & $\mathrm{Cd}$ & $\mathrm{NiO}$ & $35-52 \% \mathrm{KOH}$ & $\begin{array}{c}\mathrm{Cd}(\mathrm{s})+\mathrm{NiO}(\mathrm{s}) \\
+2 \mathrm{H} 2 \mathrm{O} \leftrightarrow \mathrm{Cd}(\mathrm{OH})(\mathrm{s}) \\
+\mathrm{Ni}(\mathrm{OH})(\mathrm{s})\end{array}$ & 1.4 & $45-80$ & 1000 \\
\hline Ni-MH & $\begin{array}{c}\mathrm{MH} \\
(\mathrm{V}, \mathrm{Ti}, \mathrm{Ni})\end{array}$ & $\begin{array}{c}\mathrm{NiOOH}, \\
\text { NiOxyhydroxide }\end{array}$ & $35-52 \% \mathrm{KOH}$ & $\begin{array}{c}\mathrm{NiOOH}+\mathrm{MH} \\
\leftrightarrow \mathrm{Ni}(\mathrm{OH})_{2}+\mathrm{M}\end{array}$ & 1.2 & $60-120$ & $300-500$ \\
\hline Li ion & Graphite & $\begin{array}{l}\mathrm{LiCoO}_{2} \\
\mathrm{LiNiO}_{2}\end{array}$ & $\begin{array}{l}\mathrm{LiPF}_{6} \text { dissolved in } \\
\text { ethylene carbonate } \\
\text { and dimethyl } \\
\text { carbonate } 1: 1\end{array}$ & $\begin{array}{l}\mathrm{xLi}+\mathrm{LiCoO}_{2} \\
\leftrightarrow \mathrm{Li}_{1+x} \mathrm{CoO}_{2}\end{array}$ & 3.0 & $190-300$ & $500-1000$ \\
\hline
\end{tabular}


replaced by nanostructure materials. Nanostructured materials provide additional electrode surface area with short path lengths for electronic and ionic transport and thus the possibility of higher reaction rates. It has been found by authors and his group [3-6] that $\mathrm{MnO}_{2}$-nano carbon electrodes show excellent electrocatalytic properties and the cost is also not high. Researchers and engineers in battery industry may further work on it for alkakine $\mathrm{MnO}_{2}$ and $\mathrm{Zn}-\mathrm{C}$ batteries. Nano-coated Ni-Co alloys synthesized and investigated by the author exhibit excellent electrochemical property for battery energy applications $[1,2]$. The material exhibited low polarization resistance and high exchange current density, that enhanced the rate of charge-discharge reaction on the electrode surface. Battery makers can use this material in Ni-Cd battery. Nano composite metal oxides, $\mathrm{ZnO}-\mathrm{Al}_{2} \mathrm{O}_{3}$ produced by Paul et al [6] performed as very good electro catalytic energy electrode. Li ion battery is the most popular and commercially used in Laptop and mobile phones. There are new developments of cathode and anode materials for Li ion battery. They are illustrated in Table $3 \mathrm{a}$ and $3 \mathrm{~b}$ respectively. Metal oxides have been studied intensively as anode materials for LIBs, such as Ti-based oxides $\left(\mathrm{TiO}_{2}\right.$ [7] and $\mathrm{Li}_{4} \mathrm{Ti}_{5} \mathrm{O}_{12}$ [8]), Mn- based oxides ( $\mathrm{MnO}$ [9], $\mathrm{Mn}_{3} \mathrm{O}_{4}$ [10], $\mathrm{Mn}_{2} \mathrm{O}_{3}$ [11] and $\mathrm{MnO}_{2}$ [12], Fe-based oxides $\left(\mathrm{Fe}_{3} \mathrm{O}_{4}[13]\right.$ and $\mathrm{Fe}_{2} \mathrm{O}_{3}$ [14]), $\mathrm{Co}_{3} \mathrm{O}_{4}$ [15], $\mathrm{NiO}$ [16] and $\mathrm{SnO}_{2}$ [17]. Among them, $\mathrm{SnO}_{2}$ is believed to be the most promising candidate, because of its low cost, environmental benignity and high theoretical specific capacity $[17,18]$. More importantly, $\mathrm{SnO}_{2}$ has the lowest operating voltages (average discharge and charge voltages of $0.3 \mathrm{~V}$ and $0.5 \mathrm{~V}$ vs. $\mathrm{Li} / \mathrm{Li}^{+}$, respectively) compared to the other transition metal oxides so that the energy density of full cells would be higher when $\mathrm{SnO}_{2}$ is used as anode material [17,19]. For $\mathrm{SnO}_{2}$-based electrode, the electrochemical processesinvolve the following two steps $[19,20]$ :

$$
\begin{aligned}
& \mathrm{SnO}_{2}+4 \mathrm{Li}^{+}+4 \mathrm{e} \leftrightarrow \mathrm{Sn}+2 \mathrm{Li}_{2} \mathrm{O} \\
& \mathrm{Sn}+x \mathrm{Li}^{+}+x \mathrm{e}^{-} \leftrightarrow \mathrm{Li}_{x} \mathrm{Sn}(0 \leq x \leq 4.4)
\end{aligned}
$$

For bulk $\mathrm{SnO}_{2}$ materials, the first reaction is believed to be irreversible so that the theoretical capacity is about $780 \mathrm{mAh} / \mathrm{g}[19,21,22]$. While for nano-sized $\mathrm{SnO}_{2}$ particles, it is reported that the first reaction becomes reversible/part reversible and the theoretical capacity can increases to the largest value of $1494 \mathrm{mAh} / \mathrm{g}[20,23]$, which is about three times

Table 3a. Existing Cathode materials for Li ion battery.

\begin{tabular}{ccccc}
\hline \hline Crystal Structure & Compound & $\begin{array}{c}\text { Specific capacity } \\
(\mathrm{mAh} / \mathrm{g})\end{array}$ & $\begin{array}{c}\text { Volumetric capacity } \\
\left(\mathrm{mAh} / \mathrm{cm}^{3}\right)\end{array}$ & Average voltage V \\
\hline \multirow{2}{*}{ Layered } & $\mathrm{LiTiS}_{2}$ & 210 & 697 & 1.9 \\
& $\mathrm{LiCoO}_{2}$ & 145 & $1363 / 550$ & 3.8 \\
& $\mathrm{LiNi}_{0.33} \mathrm{Mn}_{0.33} \mathrm{Co}_{0.33} \mathrm{O}_{2}$ & 170 & $1333 / 600$ & 3.7 \\
Spinel & $\mathrm{LiNi}_{0.8} \mathrm{Co}_{0.15} \mathrm{Al}_{0.05} \mathrm{O}_{2}$ & 200 & $1284 / 700$ & 3.7 \\
Olivine & $\mathrm{LiMn}_{2} \mathrm{O}_{4}$ & 120 & 596 & 4.1 \\
& $\mathrm{LiFePO}_{4}$ & 165 & 589 & 3.4 \\
\hline
\end{tabular}

Table 3b. Existing Anode materials for Li ion battery.

\begin{tabular}{ccccc}
\hline \hline Material & Lithiation potential (V) & Delithiation potential $(\mathrm{V})$ & $D\left(\mathrm{~cm}^{2} / \mathrm{s}\right)$ & Volume change \\
\hline Graphite & $0.07,0.10,0.19$ & $0.1,0.14,0.23$ & $10^{11}-10^{7}$ & $10 \%$ \\
$\mathrm{LTO}$ & 1.55 & 1.58 & $10^{12}-10^{11}$ & $0.20 \%$ \\
$\mathrm{Si}$ & $0.05,0.21$ & $0.31,0.47$ & $10^{13}-10^{11}$ & $270 \%$ \\
$\mathrm{Ge}$ & $0.2,0.3,0.5$ & $0.5,0.62$ & $10^{12}-10^{10}$ & $240 \%$ \\
$\mathrm{Sn}$ & $0.4,0.57,0.69$ & $0.58,0.7,0.78$ & $10^{16}-10^{13}$ & $255 \%$ \\
$\mathrm{Li}_{2} \mathrm{O}$ (amorphous) & N/A & N/A & $5 \times 10^{12}-5 \times 10^{10}$ & N/A \\
\hline
\end{tabular}


higher than that of the commercialized graphite (only $372 \mathrm{mAh} / \mathrm{g}$ ). The second process is widely known to be reversible and the lithium can be repeatedly alloyed and dealloyed with $\mathrm{Sn}$ formed in sit.

\section{Development of Future Battery}

Increasing demand of electrochemical storage energy in the computer world, server, fuel efficient aircraft and future cars has made the development of new and future battery as the emerging area of research and investment by the industrials and the government. There is a huge scope of finding new high energetic materials to form the future battery. To begin with the research and development of new innovative battery, the steps are given as follows.

1) Finding the right electrochemical reaction, where cell potential derived from Eqn. 3 will be high. For rechargeable battery, energy storage and release cycles need to be repeated many times. So the reactions must be reversible, that is the load at the external circuit is replaced by power supply. Thus any reversible electrochemical reactions with a good value of cell potential may form a rechargeable battery.

2) Synthesis of high energetic Inexpensive anode and cathode materials

3) Finding a good electrolyte which has solubility for the salt of the transferring ions as well as high ionic conductivity.

Following the above 3 steps, one find and form a new battery and characterize it electrochemically as described in the foregoing sections so that the cell will exhibit high performance in the respect of cell potential, current and specific energy. The other minor issues are as follows.

4) The electrodes should not get corroded by dissociating the chemical and the electrolyte.

5) The design of the cell should ensure that the anodic and cathodic reactions are separated so that electron released from anode can directly jump to external load through current collector if any.

\subsection{Electrochemical reaction with high potential and Energy}

There are a large number of elements and compounds from which to select potentially useful combinations for batteries. One has to find out anodic and cathodic reactions with a good cell potential and high specific energy.The half cell potential of anodic and cathodic reactions as described in the 'Introduction' section will decide the cell potential. Fig. 10a shows the half cell potential of different anodic and cathodic reaction. In this bar chart the upper bars are cathodic potential and lower ones are anodic potential. The summation of any two potentials, one from the top and other from the bottom will give reversible open circuit potential. For example for $\mathrm{Zn}$ anode (1.28) and $\mathrm{MnO}_{2}$ cathode $(0.75)$ the reversible cell potential comes out as $2.03 \mathrm{~V}$ which is lessened by cell IR and polarizations as discussed in the previous sections.It shows why Li ion battery is so popular. It is interesting to note that the future battery combination of $\mathrm{Cl}_{2}$ electrode with $\mathrm{Al}$ or $\mathrm{Mg}$ can be tried for high cell potential battery. Also from Fig. 10b which displays the energy density of the different electrode materials, It is found both $\mathrm{Al}$ and $\mathrm{Mg}$ have high energy density. It is also seen that Li metal has got the highest energy density as well as cell potential which makes $\mathrm{Li}$ ion battery unique in all applications.

The materials at anode and cathode have high electro catalytic activities so that electron release at anode
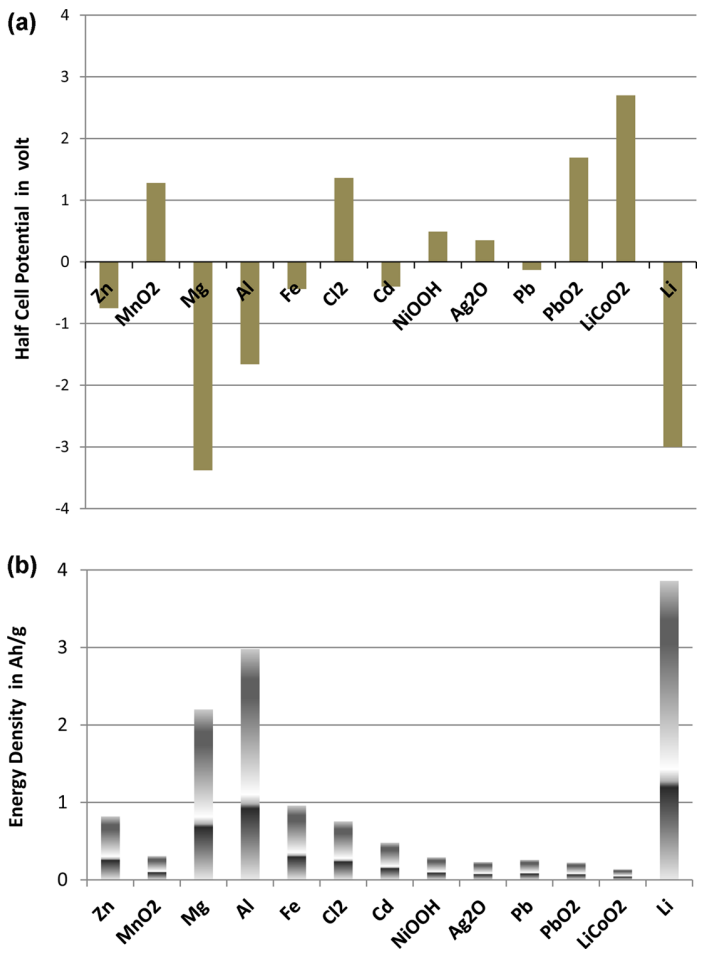

Fig. 10. Half cell Potential and Energy density of different electrode materials for Future Battery. 
and electron supply at cathode are fast, delivering a high current from a battery. Factors such as, electrode materials properties, products of reactions, kinetics and cost decide the materials for batteries to be used commercial purposes. The electro catalytic activities of the electrodes can be found out by various electrochemical tests as discussed in the section, Electrodes Materials Characterization.

\subsection{Reversible Reactions}

For rechargeable battery, the energy storage and release cycles need to be repeated many times. So the reactions must be reversible, that is the load at the external circuit is replaced by power supply. Thus any reversible electrochemical reactions with a good value of cell potential (difference in electrode potential for anodic and cathodic half cell reactions) may form a rechargeable battery. If the cell is rechargeable, cell reaction must be reversible. A reversible reaction is a chemical change in which the products can be converted back to the original reactants under suitable conditions.

- In a reversible reaction, changing the reaction conditions e.g. concentration, pressure or temperature will change the net direction the reaction goes i.e. more to the right (forward) or more to left (backward).

- It also means a reversible reaction does not go to completion in direction and all components, original reactants or ensuing products, all co-exist in the reaction mixture.

This means the reaction can go in either direction i.e.

- $\mathrm{A}+\mathrm{B}=\mathrm{C}+\mathrm{D}$ or $\mathrm{C}+\mathrm{D}==\mathrm{A}+\mathrm{B}$

So the reaction in battery chemistry should be such that on discharge the forward reaction will occur while on charging that is supplying external energy the reverse reaction can take place, giving rise to pure reactants without any intermediate products. For a battery with $\mathrm{Mg}$ and $\mathrm{Cl}_{2}$ electrodes, the discharge reaction is

$$
\mathrm{Mg}+\mathrm{Cl}_{2} \leftrightarrow \mathrm{MgCl}_{2}
$$

While on charging $\mathrm{MgCl}_{2}$ should decompose into $\mathrm{Mg}+\mathrm{Cl}_{2}$ with external electrical energy. Table 4 illustrates the different reversible reactions with energy and charge- discharge time.

For $\mathrm{MgCl}_{2}$ free energy of formation $\Delta \mathrm{G}=-641.8$ $+89.5 \mathrm{~T} \mathrm{kj} / \mathrm{m}$. So the free energy of decomposition on charging is $\mathrm{G}=641.8-0.0895 \mathrm{~T}$. at $300 \mathrm{~K}$ Energy $=$ $615 \mathrm{KJ}$ or 171 watt-hr for 1 mole or $95 \mathrm{gms} \mathrm{MgCl}_{2}$

And at $300 \mathrm{C}$ or $600 \mathrm{~K}$ Energy $=560 \mathrm{~kJ}$ or 155 what-hr for 1 mole or 95 gms $\mathrm{MgCl}_{2}$

For a battery of 30 gms $\mathrm{MgCl}_{2}, 80 \%$ discharge, the energy for charging at room temperature $=43$ watt$\mathrm{hr}$, that is a 3 volt battery charger of 1 amp rating can charge it $100 \%$ in 14 hours.

\subsection{Synthesis of high Energetic Inexpensive Anode and Cathode materials}

A good anode material should have the electro catalytic property for fast electrochemical oxidation along with good electrical conductivity, low polarization resistance, strong biocompatibility, chemical stability and anti-corrosion property. A cathode material on other hand should have capacity to capture and transfer electron rapidly with high redox potential besides low polarization resistance. Several oxides and metal alloys have been found to show good electro catalytic properties. Materials such as CoTi [24], $\mathrm{PbO}_{2}$ [25], $\mathrm{TiO}_{2}$ [26] and $\beta-\mathrm{MnO}_{2}$ [27] show very encouraging results for electrodes.

Table 4. Future Battery, Charge- discharge Energy.

\begin{tabular}{cccccc}
\hline \hline \multirow{2}{*}{ Battery System } & $\begin{array}{c}\Delta \text { G Free of charging } \\
\text { per mole kJ at 25 C }\end{array}$ & $\begin{array}{c}\text { Energy of charging } \\
\text { per battery* with } \\
80 \% \text { discharge kJ }\end{array}$ & $\begin{array}{c}\text { Equivalent } \\
\text { Electrical Energy } \\
\text { per battery watt-hr\$ }\end{array}$ & Cell Potential volt & Charging hour\# \\
\hline $\mathrm{MgCl}_{2}$ & 615 & 155 & 14.4 & 3.5 & 4 \\
$\mathrm{ZnCl}_{2}$ & 369 & 22 & 6.0 & 2.0 & 3 \\
$\mathrm{CdS}$ & 156 & 15.6 & 5.1 & 2.0 & 2.5 \\
$\mathrm{CuSO}_{4}$ & 662 & 33 & 9.1 & 1.5 & 6 \\
$\mathrm{MgF}_{2}$ & 1049 & 195 & 54 & 5.0 & 11 \\
\hline
\end{tabular}

*Assuming electrode in the battery is $10 \mathrm{~g} \#$ considering charger is 1 amp rating $\$ 1 \mathrm{~kJ}=0.2778$ watt-hr 


\subsubsection{Nano materials Electrodes}

Nano materials have significant potential for applications in energy conversion and storage devices due to their unique physical properties. Nanostructured materials provide additional electrode surface area with short path lengths for electronic and ionic transport and thus the possibility of higher reaction rates. Paul et al $[4,28]$ produced $\mathrm{MnO}_{2}$-nano carbonelectrodes by electro synthesis that exhibited high electrocatalytic properties. Fig. 11 shows the SEM structure of a few Nano materials electrodes developed by the author. It is seen that there are elongated grains and in between there is recess. This made real substrate area in $3 \mathrm{D}$ is much more than geometrical substrate area in 2D. In Fig. 11a, $\mathrm{Pt}+\mathrm{Rh}$ are deposited deposits into nanoporous anodized Al structure. So using minute quantity of expensive material, much more higher can be delivered from an electrode surface than using the pure metals themselves. Ni-Co electrode material in Fig. 11b [29,30], clearly reveals, more surface area in 3D provides more electrocatalytic substrate for electrochemical charge/discharge to take place on electrodes, giving rise to an increase in current. Fig. 11c and 11d show the surface morphology of $\mathrm{MnO}_{2}$ and $\mathrm{MnO}_{2}+\mathrm{C}$ respectively. White part represents $\mathrm{MnO}_{2}$ and dark particle represents carbon. It is seen that over the $\mathrm{MnO}_{2}$ matrix, nano-carbon particles are randomly distributed. Presence of carbon particle has prevented lateral growth of $\mathrm{MnO}_{2}$ particles. This implies that carbon particle not only acting as a high energetic electro catalytic surface but also acting as a nano grain refiner.

Again it has been reported that addition of $\mathrm{CeO}_{2}$ to the metal electrode is found to enhance the electrooxidation property of the metal oxide by several times [31-34]. The author had achieved to synthesize clean electrical energy from different biofuels, using these such high energetic nanomaterial electrodes in fuel cells [35-37]. The materials may be used for battery electrodes as well.

To synthesize high energetic battery electrodes, various types of coating methods, viz. sol gel, vapour phase deposition, chemical coating, electro coating, are adopted. For Nano structure coating, electrodeposition is an unique process with finer control of grain size, surface morphology [38] by control of current (DC, AC and pulse current), potential and chemistry of the electrolyte. It has been discussed elsewhere by the author [38] the right technique of controlling parameters to synthesize electrode by Nano deposi- tion. The performance of $\mathrm{ZnO}-\mathrm{Al}_{2} \mathrm{O}_{3}$, and $\mathrm{Ni}-\mathrm{CeO}_{2}$ $\mathrm{Cu}$., produced by electrodeposition is also encouraging and they are promising electrode materials for future battery $[6,39]$.

Several reports have been published on other nanocomposite electrode materials, for example $\mathrm{SnO}$ based glasses [40], Sn-Fe-C [41], Sn-Mn-C [42], SiC [43], and Sn-Co [44], which show improved cycling behaviour. More recently hollow nanospheres of various materials including metals, oxides and semiconductorshave been considered as potential anodes[45-48]. Preparation methods for nanospheres with hollow interiors typically involve the removal of sacrificial templates, including silica [49] and polymer latex spheres [50], or reducing metal nanoparticles. [45] The hollow Li active nanospheres serve as barriers to particle pulverisation and provide a large surface area to buffer the volume change in $\mathrm{Li}$ insertion/de-insertion, consequently improving the capacity retention. Hollow nanospheres of $\mathrm{Sb}$ with substantially superior capacity retentionthan its counterpart nanoparticles at higher rates have been reported. Among metal oxides, $\mathrm{SnO}_{2}$ has been widely studied with a theoretical specific Li storage capacity (ca. $790 \mathrm{mAh} / \mathrm{g}$ ). The main obstacle in commercial application of the $\mathrm{Sn}$ based anode materials is the pulverisation that occurs on cycling [51,52]. Nanoparticles combined with elastic hollow carbon spheres such as Sn nanoparticles encapsulated within conductive carbon nanospheres have also been investigated [53]. 1D nanowires or nanotubes of metals, semiconductors or oxides provide a route to enhanced battery materials. $\mathrm{Cu}_{6} \mathrm{Sn}_{5}$ nanowires [54] with a measured height of 5 Épm and diameter of 250 $\mathrm{nm}$ or an aspect ratio of 20 have been studied. The first charge and discharge capacity of the nanowires was $325 \mathrm{mAh} / \mathrm{g}$. Vertical arrays of one-dimensionalNanotubes of the polycrystalline $\mathrm{SnO}_{2}$ have been synthesized through an infiltration technique using $\mathrm{SnO}_{2}$ nanoparticles as starting building units and AAO as template. [55] A reversible capacity of 525 $\mathrm{mAh} / \mathrm{g}$ was retained after 80 cycles. Thus there are inexpensive high energetic electrodes available for new battery materials which can be experimented further for future battery applications. $\mathrm{Ni}-\mathrm{Co}, \mathrm{MnO}_{2}-$ $\mathrm{C}, \mathrm{SnO}_{2}$ and $\mathrm{Cu}_{6} \mathrm{Sn}_{5}$ are promising ones.

\subsection{Electrolytes}

Having obtained high energetic anode and cathode 
materials, a proper electrolyte needs to be found out. Solvents with a large stability window, good ionic conductivity, low melting and high boiling point and a low vapour pressure can make good electrolyte. There can be three types of electrolytes, aqueous, non-aqueous and solid electrolyte. In aqueous system, $\mathrm{KOH}$ is a good electrolyte with high ionic conductivity, which varies with concentration. The conductivity reaches maxima around $30 \%$ concentration that is maintained in most alkaline battery. Non aqueous electrolyte is used to prevent $\mathrm{H}_{2}$ evolution in any electrode reaction. Most non aqueous electrolytes are organic compounds such as carbonate of ethylene, dimethyl, diethyl or mixture of them. For Li ion battery, $\mathrm{LiPF}_{6}$ is dissolved into the mixture of these organic liquids. Solid electrolytes have advantages of all solid state construction, high energy density, non- corrosive and non-explosive. Solid electrolytes are most popular for Li battery. High conductive crystals and ceramic glasses such $\mathrm{Zr}$ and $\mathrm{Si}$ based oxides form good solid electrolytes. For Li ion battery $\mathrm{Li}_{7} \mathrm{La}_{2} \mathrm{Zr}_{2} \mathrm{O}_{12}$ and $\mathrm{SiS}_{2}-\mathrm{Li}_{2} \mathrm{~S}-\mathrm{Li}_{4} \mathrm{SO}_{4}$ perform as good solid electrolytes.

\section{Future Batteries}

To start with finding a new battery with high energy and cell potential, a combination of highly reactive metals with high electronegative anions is the first step. Most of the investigated, high-voltage ionic shuttles ( $\mathrm{Li}, \mathrm{Na}$, and $\mathrm{Mg}$ ) are located at the negative end of the standard electrode potential series. The other end of the standard potential series, which comprises materials such as fluorine and chlorine have not been deeply investigated for batteries. The list of future batteries is Fluoride ion battery, Chloride ion battery, $\mathrm{Mg}$ battery, $\mathrm{Na}$ battery, $\mathrm{Al}$ battery, $\mathrm{Zn}$ battery. Table 6 gives a comparison of specific energy of a few batteries. Among these the development of the most promising future batteries is discussed. For the development of the electrode materials all testing in the sections 3.0 are to be followed.

\subsection{Fluoride Ion Battery}

Fluorine is the most electronegative element in the periodic table. Thus, the fluoride ion is very stable and has a wide electrochemical stability window. It can therefore be regarded as a suitable and stable ion for charge transfer in a battery. There are only a few works on fluoride ion battery [59-61]. The transfer of the fluoride ion between two electrodes enables reversible storage of electrons by charge compensation when the electrochemical couple is either charged or discharged by the outer electric circuit of the battery.The theoretical working principle of a FIB is illustrated with an example of $\mathrm{BiF}_{3} / \mathrm{Mg}$ as electrochemical couple. The discharge is accompanied by the oxidation of the anode, e.g., $\mathrm{Mg} \rightarrow \mathrm{MgF}_{2}$, which releases two electrons to the electric circuit. The electrons reduce the cathode (consisting of a metal fluoride) to the corresponding metal, such as in $\mathrm{BiF}_{3} \rightarrow \mathrm{Bi}$. Charge neutrality is assured by $\mathrm{F}^{-}$. In theory, there is no fundamental property that renders fluoride ion batteries (FIBs) inherently more dangerous than other state-of the art batteries as long as appropriate safety measures are applied. But it has to be said, that such design principles remain to be established and therefore no clear statement on the safety is possible at the moment.

For binary fluorides, these reactions are of the following types:

$$
\begin{aligned}
& \text { Cathode reaction: } \mathrm{M}_{1} \mathrm{~F}_{\mathrm{x}}+\mathrm{xe}^{-} \rightarrow \mathrm{M}_{1}+\mathrm{xF}^{-} \\
& \text {Anode reaction: } \mathrm{M}_{2}+\mathrm{xF}^{-} \rightarrow \mathrm{M}_{2} \mathrm{Fx}_{\mathrm{x}}+\mathrm{xe}^{-} \\
& \text {Overall: } \mathrm{M}_{1} \mathrm{~F}_{\mathrm{x}}+\mathrm{M}_{2}=\mathrm{M}_{2} \mathrm{Fx}+\mathrm{M}_{1} \mathrm{E}_{\text {cell }}=\Delta \mathrm{G} /(\mathrm{xF})
\end{aligned}
$$

where $M_{1}$ is the metal used in the cathode, $M_{2}$ is the metal used in the anode, and $m$ or $n$ is the number of fluoride ions.

The battery was operated at $150^{\circ} \mathrm{C}$ by using a solid electrolyte of $\mathrm{a} \mathrm{LaF}_{3} / \mathrm{BaF}_{2}$ composite with a fluoride conductivity of $0.2 \mathrm{mS} / \mathrm{cm}$ at $\sim 150^{\circ} \mathrm{C}$.

\subsection{Chloride ion Battery}

Metal chloride/metal systems show a large Gibbs free energy change yielding a high electromotoric force (EMF) during the phase transformation, i.e., the chloride ion transfer. The data of energy densities for some electrochemical couples of these systems are listed in Table 5. The metal chloride/metal systems show theoretical energy densities which are above those of the current LIB. Moreover, this battery system can be built from abundant material resources and it is possible to use various metals (e.g. Li, $\mathrm{Na}$, $\mathrm{Mg}, \mathrm{Ca}$, and $\mathrm{Ce}$ ) or their chlorides as active material in the electrode. Thus, it is interesting to explore these systems based on chloride ion transfer in the field of rechargeable batteries, which has not been 
Table 5. Data for Chloride ion batteries

\begin{tabular}{|c|c|c|c|c|c|c|c|}
\hline \multirow[t]{2}{*}{ Cell reactions } & \multirow[t]{2}{*}{$\Delta_{\mathrm{r}} G,{ }^{b} \mathrm{~kJ} \mathrm{~mol}^{-1}$} & \multirow[t]{2}{*}{$\mathrm{n}$} & \multirow{2}{*}{$\mathrm{EMF}^{\mathrm{c}} \mathrm{V}$} & \multicolumn{2}{|c|}{$\begin{array}{l}\text { Specific capacity of cell } \\
\text { (theoret.) }\end{array}$} & \multicolumn{2}{|c|}{$\begin{array}{l}\text { Energy density } \\
\text { (theoret.) }\end{array}$} \\
\hline & & & & $\mathrm{Ah} / \mathrm{kg}$ & $\mathrm{Ah} / \mathrm{L}$ & $\mathrm{Wh} / \mathrm{kg}$ & $\mathrm{Wh} / \mathrm{L}$ \\
\hline $\begin{array}{l}\mathrm{CoCl}_{2}(\mathrm{c})+2 \mathrm{Li}(\mathrm{a}) \\
\rightarrow 2 \mathrm{LiCl}+\mathrm{Co}\end{array}$ & -4.990 & 2 & 2.58 & 372.9 & 827.9 & 962.1 & 2136.0 \\
\hline $\begin{array}{l}\mathrm{VCl}_{3}(\mathrm{c})+3 \mathrm{Li}(\mathrm{a}) \\
\quad \rightarrow 3 \mathrm{LiCl}+\mathrm{V}\end{array}$ & -642.0 & 3 & 2.21 & 451.3 & 891.4 & 997.3 & 1970.0 \\
\hline $\begin{array}{c}\mathrm{BiCl}_{3}(\mathrm{c})+3 \mathrm{Li}(\mathrm{a}) \\
\rightarrow 3 \mathrm{LiCl}+\mathrm{Bi}\end{array}$ & -838.2 & 3 & 2.89 & 239.2 & 761.0 & 691.3 & 2199.3 \\
\hline $\begin{array}{l}2 \mathrm{BiCl}_{3}(\mathrm{c})+3 \mathrm{Mg}(\mathrm{a}) \\
\quad \rightarrow 3 \mathrm{MgCl}_{2}+2 \mathrm{Bi}\end{array}$ & -1145.4 & 6 & 1.98 & 228.6 & 920.8 & 452.6 & 1823.2 \\
\hline $\begin{array}{l}\mathrm{BiCl}_{3}(\mathrm{c})+\mathrm{Ce}(\mathrm{a}) \\
\quad \rightarrow \mathrm{CeCl}_{3}+\mathrm{Bi}\end{array}$ & -669.8 & 3 & 2.31 & 176.5 & 923.4 & 407.7 & 2133.1 \\
\hline $\begin{array}{l}\mathrm{CuCl}_{2}(\mathrm{c})+\mathrm{Ca}(\mathrm{a}) \\
\quad \rightarrow \mathrm{CaCl}_{2}+\mathrm{Cu}\end{array}$ & -573.1 & 2 & 2.97 & 307.2 & 818.1 & 912.5 & 2429.8 \\
\hline $\begin{array}{l}\mathrm{CuCl}_{2}(\mathrm{c})+\mathrm{Mg}(\mathrm{a}) \\
\rightarrow \mathrm{MgCl}_{2}+\mathrm{Cu}\end{array}$ & -416.1 & 2 & 2.15 & 337.6 & 998.6 & 725.9 & 2147.0 \\
\hline $\begin{array}{l}\mathrm{CuCl}_{2}(\mathrm{c})+2 \mathrm{Na}(\mathrm{a}) \\
\rightarrow 2 \mathrm{NaCl}+\mathrm{Cu}\end{array}$ & -592.5 & 2 & 3.07 & 297.0 & 614.5 & 911.9 & 1886.5 \\
\hline $\begin{array}{l}\mathrm{CuCl}_{2}(\mathrm{c})+2 \mathrm{Li}(\mathrm{a}) \\
\rightarrow 2 \mathrm{LiCl}+\mathrm{Cu}\end{array}$ & -593.1 & 2 & 3.07 & 361.3 & 813.3 & 1109 & 2496.8 \\
\hline $\begin{array}{l}\mathrm{CuCl}(\mathrm{c})+\mathrm{Li}(\mathrm{a}) \\
\quad \rightarrow \mathrm{LiCl}+\mathrm{Cu}\end{array}$ & -264.5 & 1 & 2.74 & 252.9 & 724.7 & 693.1 & 1958.7 \\
\hline $\begin{array}{l}\mathrm{FeCl}_{2}(\mathrm{c})+2 \mathrm{Na}(\mathrm{a}) \\
\rightarrow 2 \mathrm{NaCl}+\mathrm{Fe}\end{array}$ & -465.9 & 2 & 2.41 & 311.9 & 611.7 & 751.6 & 1474.2 \\
\hline $\begin{array}{l}\mathrm{NiCl}_{2}(\mathrm{c})+2 \mathrm{Na}(\mathrm{a}) \\
\rightarrow 2 \mathrm{NaCl}+\mathrm{Ni}\end{array}$ & -509.2 & 2 & 2.64 & 305.2 & 637.9 & 805.7 & 1684.0 \\
\hline $\begin{array}{l}\mathrm{FeCl}_{3}(\mathrm{c})+\mathrm{Ce}(\mathrm{a}) \\
\quad \rightarrow \mathrm{CeCl}_{3}+\mathrm{Fe}\end{array}$ & -650.8 & 3 & 2.25 & 265.9 & 1048.7 & 598.2 & 2359.8 \\
\hline $\begin{array}{l}2 \mathrm{FeCl}_{3}(\mathrm{c})+3 \mathrm{Mg}(\mathrm{a}) \\
\quad \rightarrow 3 \mathrm{MgCl}_{2}+2 \mathrm{Fe}\end{array}$ & -1107.4 & 6 & 1.91 & 404.7 & 1045.3 & 773.0 & 1996.5 \\
\hline $\begin{array}{l}\mathrm{MnCl}_{2}(\mathrm{c})+2 \mathrm{Li}(\mathrm{a}) \\
\rightarrow 2 \mathrm{LiCl}+\mathrm{Mn}\end{array}$ & -328.3 & 2 & 1.70 & 383.6 & 782.9 & 652.1 & 1330.9 \\
\hline
\end{tabular}

Table 6. Comparison of specific energy of future batteries.

\begin{tabular}{ccccc}
\hline \hline Species & $\begin{array}{c}\text { Energy capacity } \\
\mathrm{mAh} / \mathrm{mL}\end{array}$ & $\begin{array}{c}\text { Specific Energy } \\
\mathrm{mAh} / \mathrm{g}\end{array}$ & $\begin{array}{c}\text { Reduction Potential } \\
\text { V vs. SHE }\end{array}$ & $\begin{array}{c}\text { Effective ionic radius } \\
(\mathrm{A})\end{array}$ \\
\hline $\mathrm{Li}$ & 2026 & 3861 & -3.04 & 0.76 \\
$\mathrm{Na}$ & 1128 & 1165 & -2.71 & 1.02 \\
$\mathrm{~K}$ & 591 & 685 & -2.93 & 1.38 \\
$\mathrm{Mg}$ & 3833 & 2205 & -2.37 & 0.72 \\
$\mathrm{Ca}$ & 2073 & 1337 & -2.87 & 1.00 \\
$\mathrm{Zn}$ & 5851 & 820 & -2.20 & 0.74 \\
$\mathrm{Al}$ & 8040 & 2980 & -1.67 & 0.54 \\
\hline
\end{tabular}


reported so far. A key challenge is the development of electrolytes with high chloride ion conductivity.

Solid inorganic compounds such as $\mathrm{PbCl}_{2}, \mathrm{SnCl}_{2}$, and $\mathrm{LaOCl}$ show fast chloride transfer at very high temperatures [62] and [63], which are even higher than the melting points of some metal chlorides. The cubic $\mathrm{CsSnCl}_{3}$ has a high ionic conductivity of $1 \mathrm{mS} /$ $\mathrm{cm}$ at about $100^{\circ} \mathrm{C}$ [64] and [65], but its electrochemical stability needs to be investigated.

\subsection{Mg Battery}

$\mathrm{Mg}$ as anode material has the potential advantage of a high theoretical volumetric capacity of $3832 \mathrm{mAh} / \mathrm{cm}^{3}$ (Li: $2062 \mathrm{mAh} / \mathrm{cm}^{3}$ ), its electrochemical potential is $-2.37 \mathrm{~V}$ vs. NHE. Interestingly, $\mathrm{Mg}$ does not form dendrites when electrodeposited and can therefore be used in metallic form, thus avoiding inert host materials like in the $\mathrm{Li} /$ graphite system. $\mathrm{Mg}$ is environmentally benign, safe to handle and of low cost compared to lithium. With proper design and architecture could also lead to gravimetric energy densities of $\sim 150-200 \mathrm{Wh} / \mathrm{kg}$ with an operating voltage in the $\sim 2-3 \mathrm{~V}$ range making it an attractive candidate for electrical storage systems supporting wind and solar energy, distributed energy systems, or grid operation. Sulfur or its composite can be used as cathode. The electrochemical conversion of magnesium and sulfur via the formation of a series of intermediate polysulfide $\operatorname{MgSx}(2<\mathrm{x}<8)$ has been verified by means of various analytical and electrochemical techniques [66].

The main challenge in $\mathrm{Mg}$ battery is the development of an electrolyte for reversible $\mathrm{Mg}$ shuttle. The problems are: (1) The need to develop $\mathrm{Mg}^{2+}$-ion containing non-aqueous liquid electrolytes with high ionic conductivity and dielectric constant for reversible deposition and dissolution of magnesium. (2) The need to develop a strategy to overcome, or minimize the formation of a passivating layer on the magnesium electrode that might compromise the performance of the rechargeable battery. Carborane based magnesium electrolyte [1-(1,7-carboranyl) magnesium chloride of formula $\mathrm{B}_{10} \mathrm{C}_{2} \mathrm{ClH}_{11} \mathrm{Mg}$ ] was found [67] to be electrochemically stable up to $3.2 \mathrm{~V}$ on platinum (for reversible $\mathrm{Mg}$ deposition/stripping), stainless steel (316 grade), and aluminum. Bian et al. [68] and [69] also reported the development of thiolate based electrolytes showed an oxidative stability $2.5 \mathrm{~V}$ on platinum electrode with a reversible $\mathrm{Mg}^{2+}$ ion insertion/extraction into/from $\mathrm{Mo}_{6} \mathrm{~S}_{8}$ electrode yielding a capacity as high as $40 \mathrm{mAh} / \mathrm{g}$ when tested at $0.38 \mathrm{C}$ and $45 \mathrm{mAh} / \mathrm{g}$ at $0.095 \mathrm{C}$ current rate, respectively.

The discharge performance and the cyclability of the batteries was considerably improved using NonNucleophilic Electrolytes such as tetraglyme or a binary solvent of glyme and PP14TFSI, on $\mathrm{Mg} / \mathrm{S}$ battery [66].

\subsection{Sodium ion Battery (SIB)}

SIBs have drawn increasing attention for largescale energy storage, because of the natural abundance, low cost and environmental benignity of sodium. SIBs have a theoretical specific capacity of $1165 \mathrm{mAh} / \mathrm{g}$ with a negative reduction potential of $-2.71 \mathrm{~V} v s$. SHE. Since the size of $\mathrm{Na}^{+}$(radius $\sim 1.02 \AA$ ) is larger than $\mathrm{Li}^{+}$, most materials don't have sufficiently big interstitial space to host $\mathrm{Na}^{+}$, leading to sluggish diffusion kinetics of $\mathrm{Na}^{+}$in electrode materials [9]. Therefore, a great challenge for developing SIBs is to find appropriate electrode materials capable of hosting $\mathrm{Na}^{+}$with high capacity and fast diffusion kinetics. For cathode materials, sodium-based transition metal oxides such as carbon modified $\mathrm{NaCrO}_{4}[70]$ show good electrical property and can accelerate the reversible insertion/extraction of sodium ions and the facile complementary redox reactions of $\mathrm{Cr}^{4+} / \mathrm{Cr}^{3}+$ couple. $\mathrm{Na}_{1.25} \mathrm{~V}_{3} \mathrm{O}_{8}$ nanowires as cathode [71] provides an increased electrode-electrolyte contact area, better strain accommodation, prevent self-aggregation and also shorten $\mathrm{Na}$ ion diffusion path.Sulfates have been considered as cathode candidates for SIBs $\mathrm{Na}_{2} \mathrm{M}\left(\mathrm{SO}_{4}\right) \cdot 4 \mathrm{H}_{2} \mathrm{O}(\mathrm{M}=\mathrm{Mg}, \mathrm{Fe}, \mathrm{Co}$ or $\mathrm{Ni})$ and their dehydrated derivatives $\mathrm{Na}_{2} \mathrm{M}\left(\mathrm{SO}_{4}\right)_{2}(\mathrm{M}=\mathrm{Co}$ or $\mathrm{Fe})$ show electrochemical activity at potential 3.33.4 V $v s . \mathrm{Na} / \mathrm{Na}^{+}[72,73]$. For anode materials in SIBs, various carbon materials with different structures $[74,75]$ and different morphologies (such as carbon nanowires and hollow carbon nanospheres) [76,77] have been investigated, normally delivering a reversible capacity of about $250-300 \mathrm{mAh} / \mathrm{g}$ at a voltage range from $0-3 \mathrm{~V}$ ).

Alloy-based anodes, such as $\mathrm{Sn}\left(\mathrm{Na}_{15} \mathrm{Sn}_{4}, 847 \mathrm{mAh} / \mathrm{g}\right)$ and $\mathrm{Sb}\left(\mathrm{Na}_{3} \mathrm{Sb}, 660 \mathrm{mAh} / \mathrm{g}\right)$, have attracted considerable interest due to their appropriate potential of $\mathrm{Na}^{+}$ insertion and high theoretical capacities for SIBs [78]. Among them, $\mathrm{Sn}$ is a promising candidate with an average voltage of $0.3 \mathrm{~V}\left(v s . \mathrm{Na} / \mathrm{Na}^{+}\right)$and a theoretical capacity of $790 \mathrm{mAh} / \mathrm{g}$. 
Sn nanoparticles homogeneously embedded in spherical carbon network exhibited high electrical conductivity of the $\mathrm{Sn} / \mathrm{C}$ framework promoting the reversible sodiation/desodiation.

Other batteries in these categories are $\mathrm{K}$ ion battery Ca Battery, Al battery, Zn battery which also has high theoretical energy density. But the development of these batteries is rather slow due to problems in finding the right electrode materials.

\section{Conclusions}

The demand for energy storage device is increasing. New and high energetic inexpensive electrode materials can not improve the performance of the present existing batteries but also show the route of finding non $\mathrm{Li}$ ion based battery of low cost and high performance. Nano material s metals, alloys, oxides and composite produce very high energetic electrodes materials using abundant materials on earth. Rechargeable batteries base on alternative metal elements $(\mathrm{Na}, \mathrm{K}, \mathrm{Mg}, \mathrm{Ca}, \mathrm{Zn}$ and $\mathrm{Al}$, etc.) can provide relatively high power density and energy density using abundant, low-cost materials. The final choice of anode-cathode couple for a future cell depends on the outcome of various electrochemical testing as described in the sections above.

\section{References}

[1] S. Paul, Sk Naimuddin and A. Ghosh, J. Fuel Chem. \& Tech., 2014, 42(1), 87-95.

[2] S. Paul and Sk Naimuddin, J. Fuel Cell Sci. Technol., 2015, 12, 011007.

[3] S. Paul and A. Ghosh, J. Fuel Cell Sci. Technol., 2015, 43, 344-351.

[4] S. Paul and R. Chatterjee, Namomaterials and Energy, 2015, 4, 64-72.

[5] S. Paul, J. Fuel Cell Sci. Technol., 2012, 9, 021013.

[6] S. K. Guchhait and S. Paul, J. Fuel Cell Sci. Technol., 2015, 43, 1004-1010.

[7] Y. S. Hu, L. Kienle, Y.-G. Guo and J. Maier, $A d v$. Mater, 2006, 18, 1421-1426.

[8] E. M. Sorensen, S. J. Barry, H.-K. Jung, J. R. Rondinelli, J. T. Vaughey and K. R. Poeppelmeier, Chem. Mater., 2006, 18, 482-489.

[9] K. Zhong, X. Xia, B. Zhang, H. Li, Z. Wang and L. Chen, J. Power Sources, 2010, 195, 3300-3308.

[10] J. Gao, M. A. Lowe and H. D. Abruna, Chem. Mater, 2011, 23, 3223-3227.

[11] Y. Qiu, G.-L. Xu, K. Yan, H. Sun, J. Xiao, S. Yang, S.-G. Sun, L. Jin and H. Deng, J. Mater. Chem., 2011, 21, 6346-6353.
[12] A. L. M. Reddy, M. M. Shaijumon, S. R. Gowda and P. M. Ajayan, Nano Lett., 2009, 9, 1002-1006.

[13] W.-M. Zhang, X.-L. Wu, J.-S. Hu, Y.-G. Guo and L.-J. Wan, Adv. Funct. Mater., 2008, 18, 3941-3946.

[14] M. V. Reddy, T. Yu, C. H. Sow, Z. X. Shen, C. T. Lim, G. V. Subba Rao and B. V. R. Chowdari, Adv. Funct. Mater, 2007, 17, 2792-2799.

[15] Y.-M. Kang, M.-S. Song, J.-H. Kim, H.-S. Kim, M.-S. Park, J.-Y. Lee, H. K. Liu and S. X. Dou, Electrochim. Acta, 2005, 50, 3667-3673.

[16] H. Liu, G. Wang, J. Liu, S. Qiao and H. Ahn, J. Mater. Chem., 2011, 21, 3046-3052.

[17] X. W. Lou, Y. Wang, C. Yuan, J. Y. Lee and L. A. Archer, Adv. Mater, 2006, 18, 2325-2329.

[18] J. S. Chen and X. W. Lou, Small, 2013, 9, 1877-1893.

[19] I. A. Courtney and J. R. Dahn, J. Electrochem. Soc., 1997, 144, 2045-2052.

[20] X. Zhou, L. J.Wan and Y. G. Guo, Adv. Mater., 2013, 25, 2152-2157.

[21] X. Wang, X. Cao, L. Bourgeois, H. Guan, S. Chen, Y. Zhong, D.-M. Tang, H. Li, T. Zhai, L. Li, Y. Bando and D. Golberg, Adv. Funct. Mater, 2012, 22, 2682-2690.

[22] S.-M. Paek, E.-J. Yoo and I. Honma, Nano Lett., 2009, 9, $72-75$.

[23] H.-X. Zhang, C. Feng, Y.-C. Zhai, K.-L. Jiang, Q.-Q. Li and S.-S. Fan, Adv. Mater, 2009, 21, 2299-2304.

[24] S. Cheng, H. Liu and B. E. Logan, Environ. Sci. Technol., 2006, 40, 2426-2432.

[25] J. M. Morris, S. Jin, J. Wang, C. Zhu and M. A. Urynowicz, Electrochem. Commun., 2007, 9, 17301734.

[26] Y. Li, A. Lu, H. Ding, S. Jin, Y. Yan, C. Wang, C. Zen and X. Wang, Electrochem. Commun., 2009, 11, 14961499.

[27] D. Das, P. K. Sen and K. Das, J. Appl. Electrochem., 2006, 36, 685-690

[28] S. Paul and A. Ghosh, Energy and Environment Focus, 2016, 5(1), 6-12.

[29] S. Paul and Sk Naimuddin, A. Ghosh, J. Fuel Cell Sci. Technol., 2014, 42, 87-95.

[30] S. Paul and Sk Naimuddin, J. Fuel Cell Sci. Technol., 2015, 12, 011007.

[31] M. A. Scibioh, S.-K. Kim, E. A. Cho, T.-H. Lim, S.-A. Hong and H. Y. Ha, Appl. Catal. B, 2008, 84, 773-782.

[32] C. L. Perkins, M. A. Henderson, C. H. F. Peden and G. S. Herman, J. Vac. Sci. Technol. A, 2001, 19, 1942-1946.

[33] Y. Zhou, Y. Gao, Y. Liu and J. Liu, J. Power Sources, 2010, 195, 1605-1609.

[34] C. L. Campos, C. Roldan, M. Aponte, Y. Ishikawa and C. R. Cabrera, J. Elcetroanal. Chem., 2005, 581, 206-215.

[35] S. Paul, A. Jana and P. K. Mitra, J. Inst. Eng. Interdisciplinary Div., 2007, 88, 27-30.

[36] S. Paul and P. Mondal, Int. Energy J., 2006, 7, 221-225.

[37] S. Paul and P. Mondal, J. Inst. Eng. Interdiscip., 2009, 90, 40-45.

[38] S, Paul, Namomaterials and Energy, 2015, 4, 1-9. 
[39] S. K. Guchhait and S. Paul, International Conference on Energy, Environment and Economics "ICEEE2016" Conference, Edinburgh, UK, August 16-18, 2016.

[40] Y. Idota, T. Kabuto, A. Matsufuji, Y. Maekawa and T. Miyasaki, Science, 1997, 276, 1395-1397.

[41] O. Mao and J. R. Dahn, J. Electrochem. Soc., 1999, 146, 423-427.

[42] L. Y. Beaulieu and J. R. Dahn, J. Electrochem. Soc., 2000, 147, 3237-3241.

[43] G. X. Wang, J. H. Ahn, J. Yao, S. Bewlay and H. K. Liu, Electrochem. Commun., 2004, 6, 689-692.

[44] H. Kim and J. Cho, J. Electrochem. Soc., 2007, 154, A462-A466.

[45] N. Jayaprakash, N. Kalaiselvi and C. H. Doh, J. Appl. Electrochem., 2007, 37, 567-573.

[46] Y. Wang, F. Su, J. Y. Lee and X. S. Zhao, Chem. Mater. 2006, 18, 1347-1353.

[47] X. W. Lou, Y. Wang, C. Yuan. J. Y. Lee and L. A. Archer, Adv. Mater., 2006, 18, 2325-2329.

[48] H. Kim and J. Cho, Chem. Mater., 2008, 20, 1679-1681.

[49] S.-W. Kim, M. Kim, W. Y. Lee and T. Hyeon, J. Am. Chem. Soc., 2002, 124, 7642-7643.

[50] M. Yang, J. Ma, C. Zhang, Z. Yang and Y. Lu, Angew. Chem. Int. Ed., 2005, 44, 6727-6730.

[51] J. Gao, B. Zhang, X. Zhang and B. Xu, Angew. Chem. Int. Ed., 2006, 45, 1220.

[52] Y. Wang, J. Y. Lee and H. C. Zeng, Chem. Mater, 2005, 17, 3899-3903.

[53] Y. Wang, H. C. Zeng and J. Y. Lee, Adv. Mater, 2006, $18,645-649$.

[54] W.-M. Zhang, J.-S. Hu, Y-G. Guo, S.-F. Zheng, L.-S. Zhong, W-G. Song and L.-J. Wan, Adv. Mater., 2008, 20, 1160-1165.

[55] J. F. Rohan, M. Hasan and N. Holubowitch, Electrochim. Acta, 2011, 56, 9537-9541.

[56] Y. Wang, J. Y. Lee and H. C. Zeng, Chem. Mater., 2005, 17, 3899-3903.

[57] C. J. Patrissi and C. R. Martin, J. Electrochem. Soc., 1999, 146, 3176-3180.

[58] C. R. Sides and C. R. Martin, Adv. Mater, 2005, 17, 125-128.

[59] M. A. Reddy, M. Fichtner, J. Mater. Chem., 2011, 21, 17059-17062

[60] C. Rongeat, M. A. Reddy, R. Witter and M. Fichtner, ACS Appl. Mater. Interfaces, 2014, 6, 2103-2110.
[61] C. Rongeat, M. A. Reddy, T. Diemant, R. J. Behm, M. Fichtner, J. Mater. Chem. A, 2014, 2, 20861-20872.

[62] Zh. Zhao-Karger, X. Zhao, O. Fuhr, M. Fichtner, J. Power Sources, 2014, 245, 706-711.

[63] I. V. Murin, O. V. Glumov and N. A. Mel'nikova, Russ. J. Electrochem., 2009, 45, 411-416.

[64] N. Imanaka, K. Okamoto and G. Adachi, Angew. Chem. Int. Ed., 2002, 41, 3890-3892.

[65] K. Yamada, Y. Kuranaga, K. Ueda, S. Goto, T. Okuda and Y. Furukawa, Bull. Chem. Soc. Jpn., 1998, 71, 127134.

[66] Z. Zhao-Karger, X. Zhao, D. Wang, T. Diemant, R. J. Behm, and M. Fichtner, Adv. Energy Mater, 2015, 5, 1401155.

[67] T. J. Carter, R. Mohtadi, T. S. Arthur, F. Mizuno, R. Zhang, S. Shirai and J. W. Kampf, Angew. Chem. Int. Ed., 2014, 53, 3173-3177.

[68] P. Bian, Y. NuLi, Z. Abudoureyimu, J. Yang and J. Wang, Electrochim. Acta, 2014, 121, 258-263.

[69] P.-W. Bian, Y.-N. Nuli, Zainapuguli, J. Yang and J.-L. Wang, Acta Physico-Chimica Sinica, 2014, 30, 311-317.

[70] C.-Y. Yu, J.-S. Park, H.-G. Jung, K.-Y. Chung, D. Aurbach, Y.-K. Sun and S.-K. Myung, Energy Environ. Sci., 2015, 8, 2019-2026.

[71] Y. Dong, S. Li, K. Zhao, C. Han, W. Chen, B. Wang, L. Wang, B. Xu, Q. Wei, L. Zhang, X. Xu and L. Mai, Energy Environ. Sci., 2015, 8, 1267-1275.

[72] M. Reynaud, G. Rousse, A. M. Abakumov, M. T. Sougrati, G. Van Tendeloo, J.-N.Chotard and J.M.Tarascon, J. Mater. Chem. A, 2014, 2, 2671-2680.

[73] P. Barpanda, G. Oyama, C. D. Ling and A. Yamada, Chem. Mater. 2014, 26, 1297-1299.

[74] D. A. Stevens and J. R. Dahn, J. Electrochem. Soc., 2001, 148, A803-A811.

[75] Y.-X. Wang, S.-L. Chou, H.-K. Liu and S.-X. Dou, Carbon, 2013, 57, 202-208.

[76] Y. Cao, L. Xiao, M.L. Sushko, W. Wang, B. Schwenzer, J. Xiao, Z. Nie, L.V. Saraf, Z. Yang and J. Liu, Nano lett., 2012, 12, 3783-3787.

[77] K. Tang, L. Fu, R. J. White, L. Yu, M.-M.Titirici, M. Antonietti and J. Maier, Adv. Energy Mater, 2012, 2, 873-877.

[78] Y. Xu, Y. Zhu, Y. Liu, C. Wang, Adv. Energy Mater, 2013, 3, 128-133. 